\title{
THE INFLUENCE OF CAPITAL STRUCTURE, WORKING CAPITAL ROUND, AND INTELLECTUAL CAPITAL STRUCTURE ON CORPORATE VALUE IN FOOD AND BEVERAGES SECTOR MANUFACTURING COMPANIES LISTED IN INDONESIA STOCK EXCHANGE IN 2015-2018
}

\author{
Susanto Wibowo, Ronaldo J.
}

\begin{abstract}
This study aims to examine the effect of capital structure, working capital turnover, and intellectual capital structure on firm value. The sampling method uses purposive sampling. Companies with criteria in the food and beverage sector manufacturing companies listed on the Indonesia Stock Exchange during 2015-2018. The population is 51 companies and sampling is 14 companies.

Data analysis techniques using statistical tests: multiple linear regression, descriptive testing, data normality test, heteroskedasticity test, multicollinearity test, determination test, $t$ test, and F test.

The results showed that the company's capital structure and working capital turnover significantly had a positive effect on firm value. While the intellectual capital structure does not affect the value of the company.
\end{abstract}

Keywords: Capital Structure, Working Capital Turnover, Intellectual Capital Structure, The value of the company.

\section{PRELIMINARY}

The capital market is an investment vehicle for those who have excess funds. The public invests in the capital market intending to obtain income or return on investment. Investment can be interpreted as an activity to place funds in one or more assets during a certain period in the hope of earning income and or increasing the value of the investment. Purchasing a company's shares through the capital market is one alternative form of investment that is mostly done today. Stock is a capital investment of a company. As proof of this investment, a share certificate is issued to the shareholders so that someone who holds or owns shares of a particular company becomes the owner of the company

Company value will be influenced by the company's capital structure. Debt policy needs to be managed properly and thus a corporate capital structure will be formed consisting of, equity (equity), long-term debt (long term debt). Long-term debt according to Soemarso (2017), longterm debt (long term debt) is debt with a long term, generally more than 10 years. Capital structure is a permanent expenditure which reflects the balance between long-term debt and own capital (Bambang Riyanto, 2013). The capital structure is also the proportion of funding between long-term debt and own capital. Various capital structure theories that have been developed by previous researchers try to explain how to adjust the optimal capital structure.

In this study, the company's value will also be influenced by working capital turnover. According to Agnes Sawir (2015), working capital is the overall current assets owned by the company, or it can also be intended as funds that must be available to finance the company's daily operations. Working capital is the main problem for the company. Errors in working capital are the main cause of failure of a company. Therefore, networking capital turnover must be fast. The level of effectiveness in using working capital is very important for the company's growth 
and long-term sustainability. If the company lacks working capital to expand sales and increase production, it is likely to lose revenue and profits. the company's growth and long-term sustainability. If the company lacks working capital to expand sales and increase production, it is likely to lose revenue and profits.

The company's competitive ability not only lies in the ownership of tangible assets but more on innovation, information systems, management of the organization, and its resources. One approach used in the assessment and measurement of knowledge assets is intellectual capital which has become the focus of attention in various fields, both management, information technology, sociology, and accounting. Proxies used to measure a company's Intellectual Capital can use Value Added Intellectual Coefficient (VAIC). This poses a challenge for accountants to identify, measure, and express it in financial statements. The success of the public in creating a measurement of a company's intellectual ability that is with Value Added Intellectual CapitalVAIC can be accepted by academics and practitioners economics. According to the public, the main objective in a knowledge-based economy is to create value-added. In a knowledge-based company to create value-added not from tangible assets but from intangible assets which are intellectual capital.

The main components of VAIC can be seen from the company's resources, namely physical capital (VACA-Value Added Capital Employed), human capital (VAHU-Value Added Human Capital), and structural capital (STVA-Structural Capital Value Added). Intellectual capital components such as physical capital, human capital, and structural capital are important components in creating value-added companies. Physical capital (Value Added Capital Employed-VACA) refers to relationships with third parties such as customers and suppliers (Bontis, 2001). Human capital (Value Added Human Capital-VAHU) refers to the education and expertise of an employee who increases professionalism (Kumalasari, 2013).

Intellectual capital began to be known in Indonesia since the issuance of PSAK No. 19 (Revised 2017) concerning intangible assets (intangible assets). According to PSAK No. 19 (Revised 2017), intangible assets are non-monetary assets that can be identified and do not have a physical form and have to be used in producing or delivering goods and services, leased to other parties, or for administrative purposes. Physical capital as part of intellectual capital is a resource that determines company performance. One area that attracts academic and practitioner attention is related to the use of intellectual capital as a tool to determine the value of a company (Edvinsson \& Malone in Budiarso, 2014).

Intellectual capital is believed to play an important role in increasing company value and financial performance. Companies that can utilize their intellectual capital efficiently will increase their market. The company's goal is to optimize company value. The value of the company is reflected in the price of its shares, so the increasing difference between the price of the stock with the book value of the assets of the company that shows the hidden value. More appreciation for the company's shares from investors is believed to be caused by the intellectual capital owned by the company.

The development of the economic sector that supports the smooth running of economic activity, especially the food and beverage sector in Indonesia, is very interesting to watch. Food and beverage companies are one sector that is in demand by investors, the reason is that this sector is one sector that can survive during Indonesia's economic conditions, because alone food and beverage companies are increasingly expected to provide favorable prospects in meeting the needs of the community (Devi and Ni Putu, 2012: 2). Besides, the prospect of this sector company is very good because every community needs food and drinks in life. 
Food \& Beverages Company was chosen because it plays an important role in meeting consumer needs. Community needs for food and beverage products will always be there because it is one of the basic needs. Based on this fact, food and beverage companies are considered to continue to survive. Food and beverage industry is an industry that has good development, positive growth, is very fast and will always be there because it is one of the basic needs. The food, beverage and tobacco industries are still the branches that provide the biggest contribution to the growth of the national industry.

Based on the background that has been described above, researchers are encouraged to research the title "Effects of capital structure, working capital turnover, and Intellectual Capital Structure on Company Value in Manufacturing Companies in the Food \& Beverages Sector Listed on the Indonesia Stock Exchange in 2015-2018.

\section{Formulation of the problem}

The formulation of the problem which is limited in the discussion of this thesis is as follows:

1. Does the capital structure have a significant effect on firm value?

2. Does the working capital turnover significantly influence the value of the company?

3. Does Structural Capital Value Added (STVA) affect the value of the company?

4. Does the capital structure, working capital turnover, and Structural Capital Value Added (STVA) affect the value of the company?

\section{LITERATURE REVIEW}

\section{Capital Structure}

According to Fahmi (2015) Capital Structure is: a policy adopted by companies to seek additional funds by seeking loans to banks, leasing, or by issuing bonds. Bonds (bonds) are securities (commercial paper) that include a nominal value, interest rates, and the time period in which it was issued either by the company or government and then sold to the public.

Working Capital Turnover

According to Hery (2015) Working Capital Turnover is a ratio used to measure the effectiveness of working capital (current assets) owned by a company in generating sales.

Intellectual Capital Structure

According to Clients \& Prusak (Oktavia 2014) intellectual capital as a material that can be formalized, captured, and leverage to produce a higher value asset.

The value of the company

According to I Made Sudana (2015), Corporate Value is: corporate value is the real value of income flow or cash planning.

\section{Framework for Research and Research Hypotheses:}



\section{Research Hypothesis}

H1: Capital structure has a positive effect on firm value. 
H2: Working capital turnover affects company value.

H3: Value-added structural capital (STVA) influences company value.

H4: Capital structure, working capital turnover, Value Added Structural Capital (STVA) simultaneously influence the firm value.

\section{Object of research}

The object of this study is the observation of the dependent (independent) and independent (related) variables used in the multiple linear regression analysis models to find out whether the capital structure, working capital turnover, and intellectual capital structure influence the firm's value.

\section{Population and Research Samples}

The population is a generalization area that consists of objects or subjects that have certain qualities and characteristics that are applied by researchers to be studied and then drawn conclusions. The population to be used in this study are all food and beverages manufacturing companies listed on the 2015-2018 Indonesian Stock Exchange (IDX) consisting of 51 companies.

The sample is part of the population that meets the requirements to be the object of research. In this study the sample used was a company with the following criteria.

1) Food and beverages manufacturing companies listed on the Indonesia Stock Exchange (BEI) 2015-2018

2) Food and beverages manufacturing companies which were not delisted during the observation year, namely 2015-2018

3) Food and beverage manufacturing companies that have annual reports in a row during the 2015-2018 period.

\section{Data analysis technique}

Data analysis techniques used in the study are using:

Descriptive Statistics Analysis, statistics that provide a description or description of data that can be measured by the average value (mean), standard deviation, variance, maximum, minimum, sum, range, kurtosis, and skewness distribution. (Ghozali, Imam. 2018).

Classical Assumption Test, using the normality test, multicollinearity test, autocorrelation test, and heteroscedasticity test. Normality test aims to determine whether each variable has a normal distribution or not, multicollinearity test aims to test whether in the regression model found a correlation between independent variables, autocorrelation test aims to test the linear regression model whether there is a correlation of confounding errors in period $t$ with errors in the period t-1 (previous) or not, while the heteroscedasticity test aims to test whether in the regression model there is an inequality of variance from the residuals of one observation to another. (Ghozali, Imam. 2018).

Analysis of Multiple Linear Regression, The method of multiple linear regression analyzes the relationship of independent variables to the dependent variable. This multiple linear regression analysis is used to see the effect of capital structure, working capital turnover, and intellectual capital structure on firm value in the food and beverages manufacturing companies. The formula for the method of multiple value regression is as follows (Ghozali, Imam. 2018): $\mathrm{TQ}_{\mathrm{it}}=\alpha+\beta_{1} \mathrm{DER}_{\mathrm{it}}+\beta_{2} \mathrm{PMK}_{\mathrm{it}}+\beta_{3} \mathrm{STVA}_{3 \mathrm{it}}+\mathrm{e}$

Determination Coefficient Test, Determination coefficient test $\left(\mathrm{R}^{2}\right)$ measures how far the model's ability to explain variations to the dependent variable. The coefficient of determination (R2) is between 0 to $1\left(0 \leq \mathrm{R}^{2} \leq 1\right)$. A value close to one means that the independent variables provide almost all the information needed to predict the variation of the dependent variable. (Ghozali, Imam. 2018). 
$F$ test conducted to determine the effect of independent variables on the dependent variable simultaneously. The statistical test $\mathrm{f}$ indicates whether all independent variables included in the model have a joint influence on the independent variables. The simultaneous testing criteria with a significance level $a=5 \%$ ie if the significance value $>0.05$, then the multiple linear regression model is not feasible to use, and if the significance value $<0.05$, then the multiple linear regression model is feasible to use. (Ghozali, Imam. 2018).

Test statistic $t$ shows how far the influence of one independent variable individually in explaining the variation of the dependent variable. This $t$-test is done by comparing the $t$ calculated value with the $t$-table. If the $t$-count is greater than the $t$-table, $\mathrm{H}_{1}$ is accepted. Conversely, if t-count is smaller than $\mathrm{t}$-table then $\mathrm{H}_{1}$ is rejected. The $\mathrm{t}$-table value can be seen in the statistical table with the appropriate significance level of degree of freedom. Researchers used a significant level of $95 \%$ or $a=5 \%$. The t-test criteria in this research are if the significance value $>0.05$, then $\mathrm{H} 0$ is accepted and $\mathrm{H}_{1}$ is rejected, which means that partially the independent variable has no significant effect on the dependent variable, and if the significance value $<0.05$, then $\mathrm{H} 0$ is rejected and $\mathrm{H}_{1}$ is accepted, which means that partially the independent variable has a significant effect on the dependent variable. (Ghozali, Imam. 2018).

RESEARCH RESULT

Descriptive Statistical Analysis

Table 1: Descriptive Statistics

Descriptive Statistics

\begin{tabular}{|l|r|r|r|r|r|}
\hline & \multicolumn{1}{|c|}{$\mathrm{N}$} & Minimum & Maximum & \multicolumn{1}{c|}{ Mean } & Std. Deviation \\
\hline DER & 56 & .17 & 2.12 & .9713 & .50280 \\
PMK & 56 & -14.92 & 47.31 & 6.8776 & 10.06704 \\
STVA & 56 & $-1.98 \mathrm{E} 7$ & $4.07 \mathrm{E} 6$ & $9.8180 \mathrm{E} 4$ & $3.12044 \mathrm{E} 6$ \\
Y & 56 & $1.65 \mathrm{E} 5$ & $1.29 \mathrm{E} 7$ & $2.3310 \mathrm{E} 6$ & $2.69766 \mathrm{E} 6$ \\
Valid N (listwise) & 56 & & & & \\
\hline
\end{tabular}

Source: Descriptive Statistics Data Processing Results, 2019.

Based on the table above, it can be concluded that DER has low data deviations, PMK has low data deviations, STVA has high data deviations and Company Value (Y) has low data deviations. Classic assumption test Normality test

Figure 1: Data normality test results



Source: Normality Test Data Processing Results, 2019.

Based on the picture above, it can be concluded that the normal graph pattern is seen from points that spread around the diagonal line and the distribution follows the direction of the diagonal line 
and follows the regression model. So it can be concluded that the data processed by the author is normally distributed data so that the normality test is met.

\section{Multicollinearity Test}

Table 2: Multicollinearity test results

\begin{tabular}{|c|c|c|c|}
\hline \multirow{2}{*}{\multicolumn{2}{|c|}{ Model }} & \multicolumn{2}{|c|}{ Collinearity Statistics } \\
\hline & & Tolerance & VIF \\
\hline \multirow[t]{4}{*}{1} & (Constant) & & \\
\hline & DER & ,938 & 1,066 \\
\hline & PMK &, 954 & 1,048 \\
\hline & STVA &, 982 & 1,018 \\
\hline
\end{tabular}

a. Dependent Variable: Y

Source: Attachment to VIF Test Data Results, 2019.

Based on the table above, it appears that the four independent variables (understanding taxation, education level, environmental taxpayers, tax sanctions) have a tolerance value of more than 0.10 and a VIF value of less than 10, so it can be stated that all independent variables do not occur multicollinearity.

\section{Heteroscedasticity Test}

Figure 2: Heterokedasticity test results

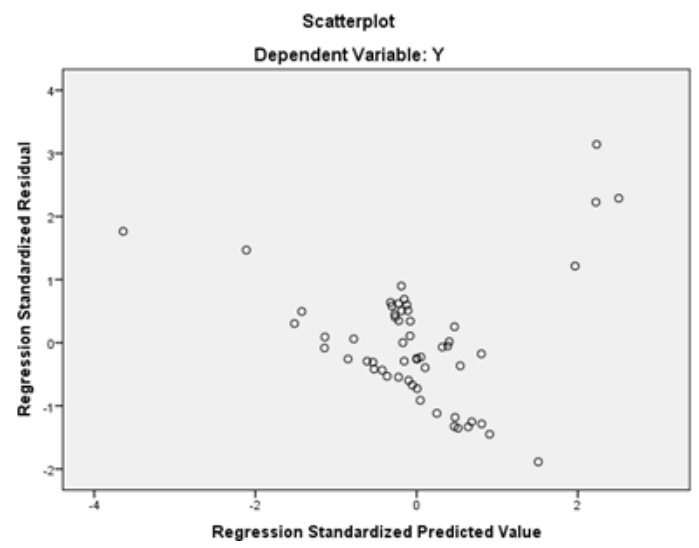

Source: Heteroscedasticity Data Processing Results, 2019.

Based on the picture above, it can be seen from the test results that the points do not form a clear pattern, and the points spread above and below the number 0 on the $\mathrm{Y}$-axis. Thus it can be concluded that there is no heteroscedasticity problem in the regression model.

\section{Multiple Linear Regression Analysis}

Table 3: Results of multiple linear regression tests

Coefficients $^{\mathrm{a}}$

\begin{tabular}{|cc|c|c|c|c|c|}
\hline \multirow{2}{*}{} & \multirow{2}{*}{ Model } & \multicolumn{2}{|c|}{$\begin{array}{c}\text { Unstandardized } \\
\text { Coefficients }\end{array}$} & $\begin{array}{c}\text { Standardized } \\
\text { Coefficients }\end{array}$ & & \multirow{2}{*}{ Sig. } \\
\cline { 2 - 6 } & $\mathrm{B}$ & Std. Error & Beta & $\mathrm{t}$ & Sig. \\
\hline \multirow{2}{*}{1} & (Constant) & $1.802 \mathrm{E} 6$ & 658162.488 & & 2.737 & .008 \\
& DER & $1.662 \mathrm{E} 6$ & 611983.695 & .310 & 2.715 & .009 \\
& PMK & -158055.032 & 30305.935 & -.590 & -5.215 & .000 \\
& STVA & .024 & .096 & .028 & .247 & .806 \\
\hline
\end{tabular}

a. Dependent Variable: Y

Source: Results of Multiple Linear Regression Data Processing, 2019.

TQit $=\alpha+\beta 1$ DERit $+\beta 2$ PMKit $+\beta 3$ STVA $\beta 3$ it $+\mathrm{e}$ 
$\mathrm{Q}=1,802+1,662 \mathrm{DER}-158055.032 \mathrm{PMK}+0.024 \mathrm{STVA}+\mathrm{e}$

The coefficient value for the constant is 1.802 , the coefficient value of the capital structure is +1.662 , the value of the working capital turnover coefficient is -158055.032 and the coefficient value of the intellectual capital structure is +0.024 .

Determination Coefficient Test.

Table 4: Test results for the coefficient of determination

Model Summary

\begin{tabular}{|l|c|r|r|r|}
\hline Model & \multicolumn{1}{|c|}{$\mathrm{R}$} & $\begin{array}{c}\mathrm{R} \\
\text { Square }\end{array}$ & $\begin{array}{c}\text { Adjusted } \\
\text { R Square }\end{array}$ & $\begin{array}{l}\text { Std. Error of } \\
\text { the Estimate }\end{array}$ \\
\hline 1 & $.604^{\mathrm{a}}$ & .365 & .329 & $2.21034 \mathrm{E} 6$ \\
\hline
\end{tabular}

Source: Results of the Determination Coefficient Test Data, 2019.

The results of the regression with the OLS (Ordinary Least Square) method obtained R2 (Determination Coefficient) of 0.365 , meaning that the dependent variable (Y) in the model that is Company Value $(\mathrm{Q})$ is explained by independent variables namely the Capital Structure variable (DER), Working Capital Turnover (DER) FMD), and Intellectual Capital Structure (STVA) of $36.5 \%$, while the remaining $63.5 \%$ is explained by other factors outside the model.

F test

Table 5: $\mathrm{F}$ test results

ANOVA $^{\mathrm{b}}$

\begin{tabular}{|c|c|c|c|c|c|c|}
\hline & & $\begin{array}{l}\text { Sum of } \\
\text { Squares }\end{array}$ & df & $\begin{array}{c}\text { Mean } \\
\text { Square }\end{array}$ & $\mathrm{F}$ & Sig. \\
\hline \multirow[t]{3}{*}{1} & Regression & $1.462 \mathrm{E} 14$ & 3 & \multirow{3}{*}{$\begin{array}{l}4.873 \mathrm{E} 13 \\
4.886 \mathrm{E} 12\end{array}$} & \multirow[t]{3}{*}{9.975} & \multirow[t]{3}{*}{$.000^{\circ}$} \\
\hline & Residual & $2.541 \mathrm{E} 14$ & 52 & & & \\
\hline & Total & $4.003 \mathrm{E} 14$ & 55 & & & \\
\hline
\end{tabular}

a. Predictors: (Constant), STVA, PMK, DER

b. Dependent Variable: Y

Source: F-Test Data Processing Results, 2019.

Based on the above table, the results of the F test can be explained as follows:

Effect of capital structure, working capital turnover and intellectual capital structure on firm value $(\mathrm{H} 4)$

Simultaneous test results ( $F$ test) show that the significance level of $0,000<0.05$, then Ho is rejected and $\mathrm{Ha}$ is accepted so that it can be concluded that capital structure, working capital turnover, and intellectual capital structure have a simultaneous influence on firm value.

\section{Statistical Test $\mathbf{t}$}

Table 6: T-test results

Coefficients $^{a}$

\begin{tabular}{|c|c|c|c|c|c|c|}
\hline \multirow{2}{*}{\multicolumn{2}{|c|}{ Model }} & \multicolumn{2}{|c|}{$\begin{array}{l}\text { Unstandardized } \\
\text { Coefficients }\end{array}$} & \multirow{2}{*}{\begin{tabular}{|c|}
$\begin{array}{c}\text { Standardized } \\
\text { Coefficients }\end{array}$ \\
Beta \\
\end{tabular}} & \multirow[b]{2}{*}{$\mathrm{t}$} & \multirow[b]{2}{*}{ Sig. } \\
\hline & & $B$ & Std. Error & & & \\
\hline & (Constant) & $1.802 \mathrm{E} 6$ & 658162.488 & & 2.737 & .008 \\
\hline & DER & $1.662 \mathrm{E} 6$ & 611983.695 & .310 & 2.715 & .009 \\
\hline & PMK & -158055.032 & 30305.935 & -.590 & -5.215 & .000 \\
\hline & STVA & .024 & .096 & .028 & .247 & .806 \\
\hline
\end{tabular}

a. Dependent Variable: Y 
Source: Statistical Test Data Processing Results t, 2019.

Based on the table above, the t statistical test can be explained as follows:

Effect of capital structure on firm value (H1)

Based on the test results of understanding taxation variables have a significant level of 0.008 $<0.05$, this shows that capital structure has a significant effect on firm value.

Effect of working capital turnover on firm value (H2)

Based on the test results of understanding taxation variables have a significant level of 0.009 $<0.05$, this shows that working capital turnover has a significant effect on firm value.

\section{Effect of intellectual capital structure on firm value (H3)}

Based on the test results of understanding taxation variables have a significant level of 0.806> 0.05 , this shows that the structure of intellectual capital does not significantly influence the value of the company.

\section{DISCUSSION}

\section{Effect of capital structure on firm value (H1)}

Variable capital structure to firm value. This is evidenced by the significant level of 0.008 $<0.05$ and shows the t-test results of 2.715> 1661788.560. This shows that capital structure has a significant effect on firm value. At some point the capital structure can increase the value of the company because of the benefits derived from the use and growth of capital structure. In a company capital structure is closely related to investment so that in this case the source of funds will be used to finance the investment project. The results of this study support the research conducted by Prastuthi et al (2016) which states that capital structure influences firm value.

\section{Effect of working capital turnover on firm value (H2)}

Variable working capital turnover on firm value. This is evidenced by the significant level of $0.009<0.05$ and shows the t-test results of $-5.215>158055.032$. This shows that working capital turnover has a significant effect on firm value. This means, if the working capital turnover (PMK) has increased, the Company Value $(\mathrm{Q})$ will increase. The better the growth of working capital turnover (PMK) means that the company's project in the future is considered better, meaning that the better the value of the company in the eyes of investors. vice versa the lower the working capital turnover of a company or leads to negative numbers, the value of the company will suffer losses. The results of this study support the research conducted by Amdani and Desnerita (2015) which states that working capital turnover affects the firm's value.

\section{Effect of intellectual capital structure on firm value (H3)}

Variable structure of intellectual capital on firm value. This is evidenced from the significant level of $0.806>0.05$ and shows the results of the $t$-test of $0.247>0.24$. This shows that the structure of intellectual capital does not affect the value of the company. This means, if the Intellectual Capital Structure (STVA) has increased, the Company Value (Q) has not increased. The results of this study are different from the research conducted by Devi, Budiasih $\&$ Badera (2017) which states that the structure of intellectual capital influences company value. Effect of capital structure, working capital turnover and intellectual capital structure on firm value (H4)

Simultaneous test results (F test) showed that the F-calculated value of 20.444> from F table 2.47 and with a significance level of $0.000<0.05$ Simultaneous test results (F test) showed that the significance level of $0,000<0.05$, then Ho is rejected and $\mathrm{Ha}$ is accepted so that it can be concluded that the capital structure, working capital turnover, and intellectual capital structure have a simultaneous influence on the value of the company. Synonymous with Rahman, Adhitya (2015). 


\section{CONCLUSION}

This study aims to analyze the effect of capital structure, working capital turnover, and intellectual capital structure on firm value. This study uses 14 samples of food and beverage manufacturing companies in the Indonesia Stock Exchange from 2015 to 2018. Based on the analysis of the discussions that have been carried out using multiple regression analysis, the following conclusions are obtained:

Capital structure variable has a significant positive effect on firm value because of the probability of its significance (Sig.) Is $0.009<0.05$ and obtained $t$ count $>t$ table is 2.715> 1661788.560 This means that capital structure has a positive effect on firm value. This shows the higher level of an entity in carrying out its capital structure and funding well, the higher the value of the company. This is because the company must be right in making funding decisions regarding the capital structure that really must be considered by the company. After all, the structure of the company's determination will affect the company's value. The working capital turnover variable has a significant negative effect on firm value because of the probability of significance (Sig.) Is $0,000<0.05$ and the value of $t$ count $>$ t table is $-5,215>-158055,032$. This means that working capital turnover harms firm value. This shows the lower the level of working capital turnover, the higher the value of the company. This is because companies increase their current assets and minimize current liabilities compared to sales. So the lower the working capital turnover, the higher the value of the company. The intellectual capital structure variable does not affect the firm value, the probability of its significance (Sig.) Is 0.806>0.05 and the value of $t$ count $>t$ table is $2.47<0.24$. This means that the structure of intellectual capital does not affect the value of the company. This means, if the intellectual capital structure has increased, then the value of the company has not increased.

Of these three independent variables have a relationship with the firm value that the ability of the independent variable namely capital structure, working capital turnover, and intellectual capital structure can explain the value of the company is only $36.5 \%$. While the remaining $63.5 \%$ is explained or influenced by other factors such as profitability, financial performance, company growth, company size, etc. in addition to the independent variable.

\section{BIBLIOGRAPHY}

Agnes Sawir, 2015, Financial Performance Analysis and Corporate Financial Planning, Gramedia Pustaka Utama, Jakarta.

Edvinsson, L. And Malone, M. (1997). Intellectual Capital: Realizing Your Company's True Value by Finding Its Hidden Brainpower. HarperCollins. New York.

Ghozali, Imam. 2018. Application of Multivariate Analysis with the SPSS Program. Semarang: Diponegoro University Publisher Agency.

Kumalasari, P. D, and Astika, I.B.P. 2013. The Effect of Intellectual Capital on Financial Performance on the Indonesia Stock Exchange. Journal of the Faculty of Economics and Business, Udayana University. Vol. 02. No. 05.

Hery 2015. Analysis of Financial Statements. Issue 1. Yogyakarta: Center For Academic Publishing Services.

Indonesian Accounting Association (IAI). 2017. Financial Accounting Standards (PSAK) revised in 2017. Salemba Empat. Jakarta: IAI

Sudana, I Made. 2015. Corporate Financial Management, Second Edition. Jakarta: Erlangga.

Amdani and Desnerita. "The Effect of Capital Structure and Work Capital Turnover on Profitability (Empirical Study of Corporate Tax Payers Checked by Central Jakarta Middle Tax Office)". Accounting journal. September 2015, Vol. 19 (3): 398-419. 
Devi, Ni Putu Yunita, and Ni Made Adi Erawati. 2014. "Effect of Managerial Ownership, Leverage, and Company Size on Manufacturing Company Dividend Policy". E-Journal of Udayana University 9.3 (2014): 709 - 716.

Devi, Budiasih \& Badera. "The Effects of Enterprise Risk Management Disclosures and Intellectual Capital Disclosures on Company Value". Journal of Accounting and Finance. June 2017, Vol.14 (1): 20-45.

Oktavia, Maria Carolin. "The Effect of Intellectual Capital on Financial Performance, Growth, and Market Value (Empirical Study of Construction, Property \& Real Estate Companies Listed on the Indonesia Stock Exchange 2009-2012)". Bachelor Thesis. Semarang: Faculty of Economics and Business, Diponegoro University, 2014.

Prastuthi, Rai Ni Kadek, \& I Gede Merta Sudiartha. "Effect of Capital Structure, Dividend Policy, and Company Size on Company Value in Manufacturing Companies on the Indonesia Stock Exchange". E-Journal of Udayana University Management. 2016 Vol.5 (5): 1572-1598.

Rahman, Adhitya. "The Effect of Dividend Policy, Debt Policy, Investment Decisions, and Profitability of Company Value on Manufacturing Companies listed on the IDX". Journal

\section{Sumber lain:} of Economics, Riau University. 2015 Vol.2 (2).

www.idx.co.id

www.scholar.google.com

www.sahamok.com 